\title{
Synthesis and Structural Confirmation of Natural
}

\section{1,3-Diarylpropanes}

\author{
Paulo A. de Almeida ${ }^{\mathrm{a}}$, Silas V. Fraiz, Jr. ${ }^{\mathrm{a}}$, and Raimundo Braz-Filho ${ }^{\mathrm{b}_{*}}$ \\ ${ }^{a}$ Departamento de Química, Instituto de Ciências Exatas, Universidade Federal Rural \\ do Rio de Janeiro, 23851-970 Seropédica - Rio de Janeiro, Brazil; \\ ${ }^{\mathrm{b}}$ Setor de Química de Produtos Naturais, LCQUI - CCT, Universidade Estadual do
}

Norte Fluminense, 28051-620 Campos - RJ, Brazil

\begin{abstract}
1-(4'-Hidroxi-5' -metil-2'-metoxifenil)-3-(2"-hidroxi-4",5"-metileno-dioxifenil)propano (7), 1,3-diarilpropano isolado de Iryanthera laevis (Myristicaceae), 1-(4'-hidroxi-2'-metoxifenil)-3(4"-hidroxifenil)propano (2, broussonina B) e 1-(2'-hidroxi-4'-metoxifenil)-3-(4"-hidroxifenil) propano (1, broussonina A), isolados de Broussonetia papyrifera Vent. (Moraceae), e 1-(2',4'-dimetoxifenil)-3-(4"-hidroxifenil)propano (4), um produto sintético oriundo da hidrogenação catalítica da 4-O-benzil-2',4'-dimetoxichalcona, foram sintetizados. A rota sintética utilizada envolveu hidrogenação catalítica (Pd-C 10\%) de chalconas obtidas por condensação aldólica de acetofenonas e benzaldeídos adequadamente substituídos.
\end{abstract}

1-(4'-Hydroxy-5'-methyl-2'-methoxyphenyl)-3-(2"-hydroxy-4",5"-methylenedioxyphenyl) propane (7), 1,3-diarylpropane isolated from Iryanthera laevis, 1-(4'-hydroxy-2'-methoxyphenyl)3-(4"-hydroxyphenyl)propane (2, broussonin B) and 1-(2'-hydroxy-4'-methoxyphenyl)-3-(4"-hydroxyphenyl)propane (1, broussonin A), isolated from Broussonetia papyrifera Vent. (Moraceae), and 1-(2',4'-dimethoxyphenyl)-3-(4"-hydroxyphenyl)propane, a synthetic product prepared by catalytic hydrogenation of 4-O-benzyl-2',4'-dimethoxychalcone, were synthesized. The synthetic pathway employed in this work involved the catalytic hydrogenation of chalcones obtained by base condensation of acetophenones and benzaldehydes.

Keywords: Iryanthera laevis, 1,3-Diarylpropanes, reduction of chalcones

\section{Introduction}

1,3-Diarylpropanes have been isolated mainly from Virola and Iryanthera species (Myristicaceae) ${ }^{1-4}$. However, in 1980 Takasugi and co-workers reported the structures of the new 1,3-diarylpropanes broussonins A (1), B (2) and C (3) isolated from Broussonetia papyrifera Vent. (Moraceae), which revealed antifungal activities in tissues of this plant inoculated with Fusarium solani f. sp. mori ${ }^{5}$. These diarylpropanoids, classified as phytoalexins, were not detected in the uninoculated tissues of this same plant and showed activity against Bipolaris leersiae at $10^{-4}-10^{-5}$ $\mathrm{M}^{6}$.

1,3-Diarylpropanes have been synthesized to confirm structures of natural products ${ }^{7-9}$. In a previous study ${ }^{7}$, the synthesis of 1-(2'-hydroxy-5'-methyl-4'-methoxyphenyl)3-(2"-hydroxy-4",5"-methylenedioxyphenyl)propane (6) was described, in order to confirm the structure proposed

*e-mail: pafonso@ufrrj.br for the natural product previously isolated from Iryanthera laevis $^{2}$. Comparison of the spectral data of the synthetic and natural products revealed different compounds and, consequently, a new isomeric structure 1-(4'-hydroxy-5'methyl-2'-methoxyphenyl)-3-(2"-hydroxy-4",5"-methyle nedioxyphenyl)propane (7) was proposed ${ }^{7}$.

In this paper, we report the synthesis of four 1,3-diarylpropanes: 1-(4'-hydroxy-2'-methoxyphenyl)-3-(4''-hydroxyphenyl)propane (2, broussonin B) to confirm the structure proposal for the natural product isolated from Broussonetia papyrifera Vent. ${ }^{5}, 1-\left(4^{\prime}\right.$-hydroxy-5'-methyl2'-methoxyphenyl)-3-(2"-hydroxy-4", 5"-methylenedioxyphenyl)propane (7) to confirm the structure proposal ${ }^{7}$ for the natural product isolated from Iryanthera laevis ${ }^{2}, 1-(2$ 'hydroxy-4'-methoxyphenyl)-3-(4''-hydroxyphenyl) propane $(\mathbf{1}$, broussonin A), a product previously synthesized by another synthetic pathway ${ }^{9}$, and 1-(2',4'-di- 
methoxyphenyl)-3-(4"'-hydroxyphenyl)propane (4), which was prepared for comparative ${ }^{13} \mathrm{C}-\mathrm{NMR}$ analysis.

The structures of the synthetic compounds were characterized by analysis of spectral data, mainly mass, one(1D) and two-dimensional (2D) ${ }^{1} \mathrm{H}$ and ${ }^{13} \mathrm{C}$-NMR.

\section{Results and Discussion}

The synthetic pathway employed in order to obtain the desired 1,3-diarylpropanes $(\mathbf{1}, \mathbf{2}, \mathbf{4}$ and $\mathbf{7})$ involved the<smiles>[R20]Oc1ccc(CCCc2ccc([R20])c([R3])c2)c([R])c1</smiles>

$1 \mathrm{R}_{1}=\mathrm{R}_{3}=\mathrm{R}_{4}=\mathrm{H}, \mathrm{R}_{2}=\mathrm{Me}$ (Broussonin $\mathrm{A}$ )

$2 \mathrm{R}_{1}=\mathrm{Me}, \mathrm{R}_{2}=\mathrm{R}_{3}=\mathrm{R}_{4}=\mathrm{H}$ (Broussonin $\mathrm{B}$ )

$3 \mathrm{R}_{1}=\mathrm{R}_{2}=\mathrm{R}_{4}=\mathrm{H}, \mathrm{R}_{3}=$ Prenyl (Broussonin $\mathrm{C}$ )

$4 \mathrm{R}_{1}=\mathrm{R}_{2}=\mathrm{Me}, \mathrm{R}_{3}=\mathrm{R}_{4}=\mathrm{H}$

$5 \mathrm{R}_{1}=\mathrm{R}_{4}=\mathrm{Me}, \mathrm{R}_{2}=\mathrm{H}, \mathrm{R}_{3}=\mathrm{OH}$<smiles>[R20]Oc1ccc(C(=O)/C=C/c2ccc(OCc3ccccc3)cc2)c(O[R20])c1</smiles>

$8 \mathrm{R}_{1}=\mathrm{Me}, \mathrm{R}_{2}=\mathrm{CH}_{2} \mathrm{Ph}$

$9 \mathrm{R}_{1}=\mathrm{CH}_{2} \mathrm{Ph}, \mathrm{R}_{2}=\mathrm{Me}$

$10 \mathrm{R}_{1}=\mathrm{R}_{2}=\mathrm{Me}$ base-catalysed condensation of the appropriate acetophenones (16, 18, 19 and 20, Scheme 1) with benzaldehydes ( 23 and 25, Scheme 2) to produce the corresponding chalcones $(\mathbf{8}, 9,10$ and 11$)$ which were submitted to catalytic hydrogenation. Acetophenones $\mathbf{1 5}$ and $\mathbf{1 7}$ were prepared from resorcinol (12, Scheme 1) and protected by hydroxyl group benzylation, before or after appropriate methylation to furnish 16, 18 and 19 or dimethylated 20. Benzaldehyde 22 obtained from piperonal (21, Scheme 2) and $\mathbf{2 4}$ were

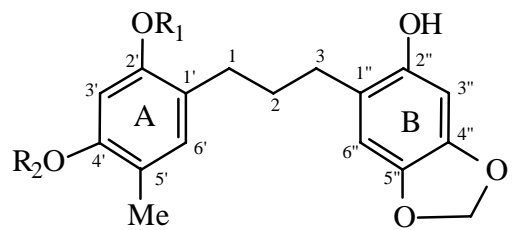

$6 \mathrm{R}_{1}=\mathrm{H}, \mathrm{R}_{2}=\mathrm{Me}$

$7 \mathrm{R}_{1}=\mathrm{Me}, \mathrm{R}_{2}=\mathrm{H}$<smiles>COc1cc(OCC(C)C)c([N+](=O)[O-])cc1C(=O)/C=C/c1cc2c(cc1OCc1ccccc1)OCO2</smiles>

11<smiles>CC#CC1CC(=O)c2ccc(OC)cc2OC1c1ccc(OCc2ccccc2)cc1</smiles>

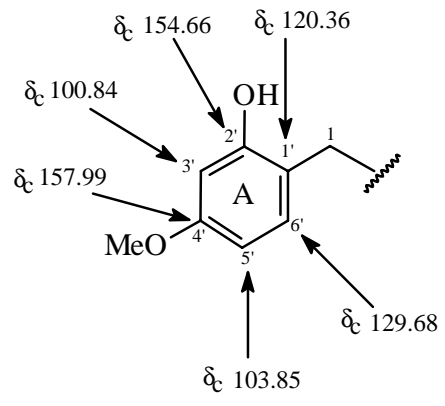

$1 \mathrm{a}$

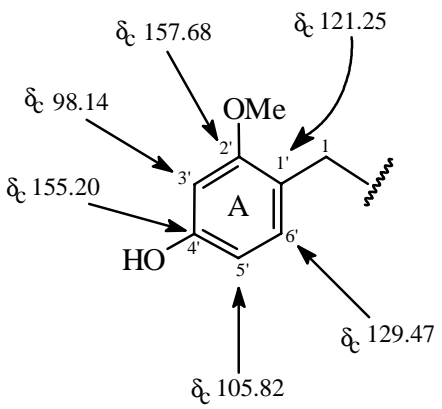

2a

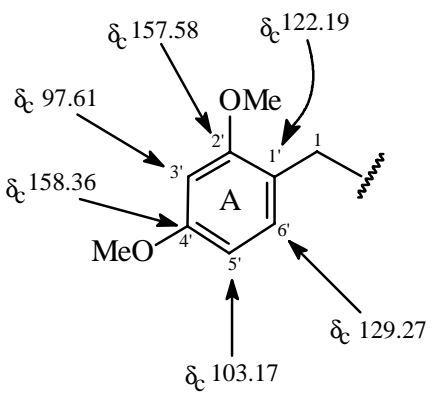

4a 
protected by hydroxyl group benzylation, in order to stabilize the substrates towards the basic conditions of the condensation reaction: $18+25 \rightarrow \mathbf{8} ; \mathbf{1 9}+\mathbf{2 5} \rightarrow \mathbf{9} ; \mathbf{2 0}+\mathbf{2 5} \rightarrow$ $\mathbf{1 0} ; \mathbf{1 6}+\mathbf{2 3} \rightarrow \mathbf{1 1}$. Thus, 1,3-diarylpropanes 1, 2, 4 and 7 were prepared by catalytic hydrogenation of the chalcones $\mathbf{8 , 9}, \mathbf{1 0}$, and 11, respectively. Chalcone 9a which has an unprotected 2'-hydroxyl group can undergo chalcone(9a)flavanone(9b) equilibrium under the catalytic hydrogenation conditions which were used. Thus, a mixture of 1,3-diarylpropane and the corresponding dihydrochalcone was obtained. Using the same conditions, this partial reduction was not observed after the isomeric equilibrium was blocked by a 2'-hydroxyl group benzylation (9) or methylation (10).

The structure of 1-(4'-hydroxy-2'-methoxyphenyl)-3(4',-hydroxyphe-nyl)propane (2) proposed for the natural product isolated from Broussonetia papyrifera Vent. $^{5}$ and 1-(4'-hydroxy-5' -methyl-2'-methoxyphenyl)-3-( 2"-hydroxy-4",5"-methylenedioxyphenyl)propane (7) proposed for the natural product isolated from Iryanthera laevis ${ }^{2}$ were confirmed by comparison with the synthetic products.

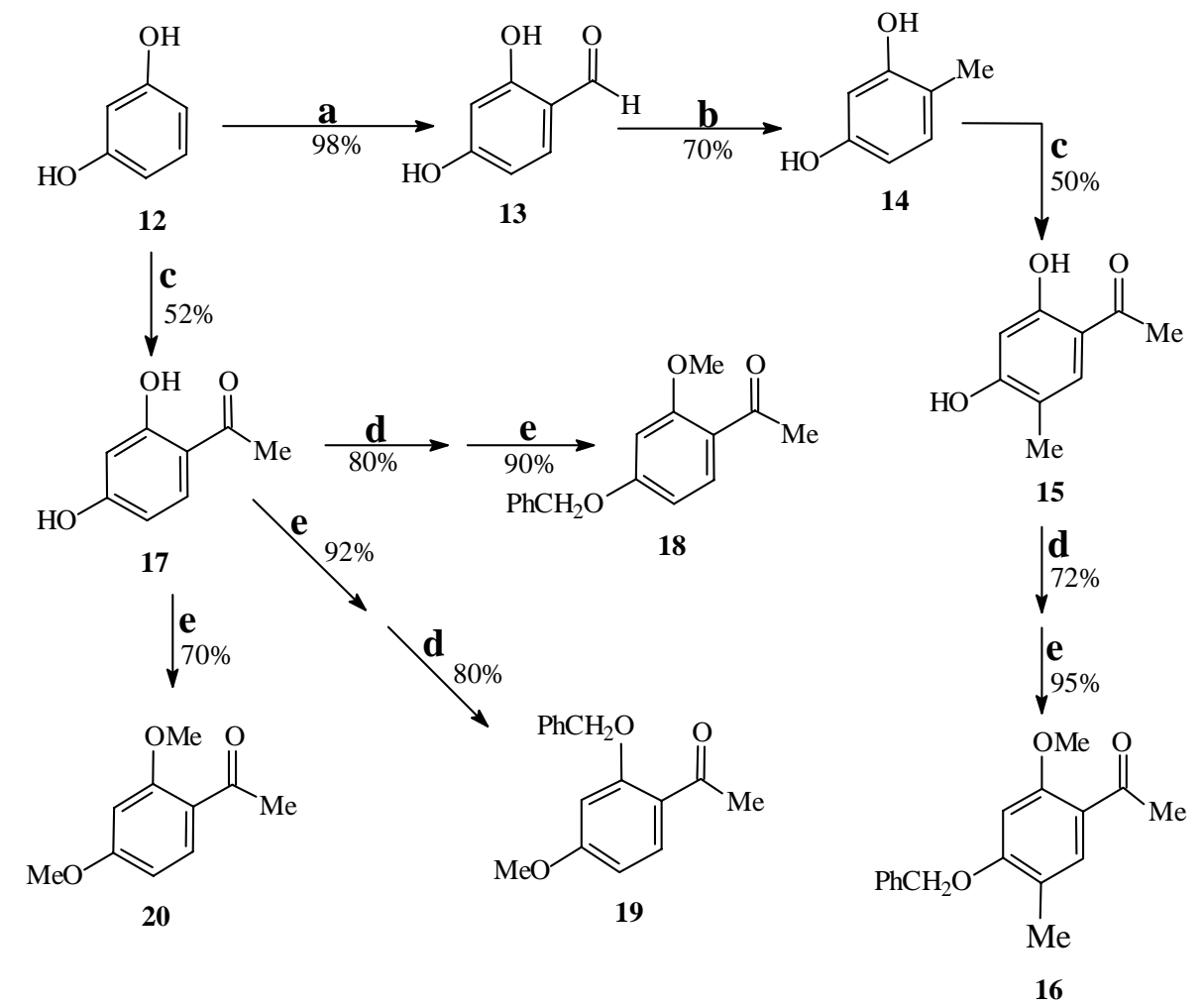

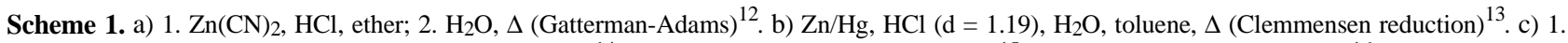
$\mathrm{AcOH}, \mathrm{ZnCl}_{2}, \Delta ; 2$. $\mathrm{HCl}(1: 1)\left(\right.$ Houben/Hoesch reaction) ${ }^{14}$. d) $\mathrm{PhCH}_{2} \mathrm{Cl}, \mathrm{K}_{2} \mathrm{CO}_{3}$, $\mathrm{KI}$, acetone, $\Delta^{15}$. e) $\mathrm{Me}_{2} \mathrm{SO}_{4}, \mathrm{~K}_{2} \mathrm{CO}_{3}$, acetone, $\Delta^{16}$.

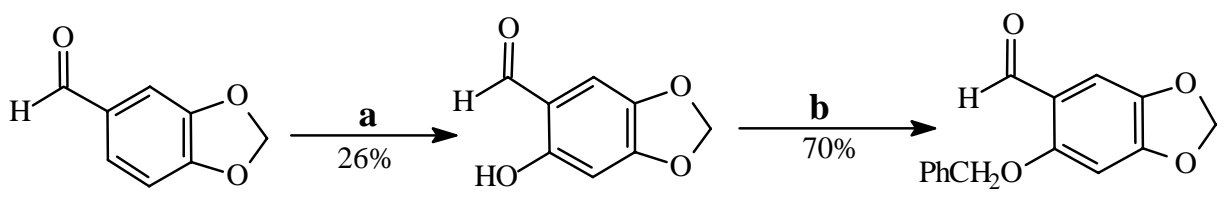

21 22<smiles>CCCCCC=O</smiles>

24
23<smiles>O=Cc1ccc(Oc2ccccc2)cc1</smiles>

25

Scheme 2. a) $1 . \mathrm{HNO}_{3}(\mathrm{~d}=1.38) ; 2 . \mathrm{FeSO}_{4}, \mathrm{NH}_{4} \mathrm{OH}, \mathrm{EtOH} ; 3 . \mathrm{NaNO}_{2}, \mathrm{CuSO}_{4}, \mathrm{H}_{2} \mathrm{SO}_{4}{ }^{8}$. b) $\mathrm{PhCH}_{2} \mathrm{Cl}, \mathrm{K}_{2} \mathrm{CO}_{3}, \mathrm{KI}$, acetone, $\Delta^{15}$. 
Comparative analysis of the ${ }^{13} \mathrm{C}-\mathrm{NMR}$ spectral data of 1, 2 and 4 revealed chemical shift values for the characterization of the aromatic ring A 2'-methoxy-4'-hydroxy-, 2'-hydroxy-4'-methoxy- and 2',4'-dimethoxy-, as shown in the partial structures 1a, 2a and 4a corresponding to 1,3-diarylpropanoids $\mathbf{1}, \mathbf{2}$ and $\mathbf{4}$, respectively. This analysis also allowed observation of chemical shift modifications of the signals of the methine carbons $\mathrm{CH}_{-3}{ }^{\prime}$ ' and $\mathrm{CH}-5$ ' as a consequence from a $\gamma$-effect of the methyl group of the 2'-methoxy or 4'-methoxy: i) $\mathrm{CH}-3$ ' $\left[\delta_{\mathrm{C}}=97.61(\mathbf{4 a})\right.$ $100.84(\mathbf{1 a})=-3.23 \mathrm{ppm}$ and $\delta_{\mathrm{C}}=97.61(\mathbf{4 a})-98.14(\mathbf{2 a})=$ - $0.53 \mathrm{ppm}]$; ii) $\mathrm{CH}-5,\left[\delta_{\mathrm{C}}=103.17(\mathbf{4 a})-105.82(\mathbf{2 a})=-\right.$ $2.65 \mathrm{ppm}]$. The modifications, a consequence of methylation of a hydroxyl group, may be deduced by comparison of the chemical shifts of the quaternary carbons C-2' and C-4' revealing a deshielding $\beta$-effect.

The homonuclear ${ }^{1} \mathrm{Hx}{ }^{1} \mathrm{H}-\mathrm{COSY}$ and heteronuclear $\left({ }^{13} \mathrm{C}\right.$ detected, conventional method) ${ }^{13} \mathrm{Cx}^{1} \mathrm{H}-\mathrm{COSY}-{ }^{1} \mathrm{~J}_{\mathrm{CH}}$ (direct spin-spin interaction of carbon-13 and hydrogen via one bond) and ${ }^{13} \mathrm{Cx}^{1} \mathrm{H}-\mathrm{COSY}-{ }^{n} \mathrm{~J}_{\mathrm{CH}}[\mathrm{n}=2$ and 3 , COLOC, long-range coupling of carbon-13 and hydrogen via two $\left({ }^{2} \mathrm{~J}_{\mathrm{CH}}\right)$ and three $\left({ }^{3} \mathrm{~J}_{\mathrm{CH}}\right)$ bonds] 2D shift-correlated NMR spectra of the synthetic products were also used to assign unambiguously the chemical shifts of the carbon and hydrogen atoms and to reexamine values described in the literature ${ }^{10,11}$. The results obtained by careful analysis of these spectra of 1, 2, 4 and $\mathbf{7}$ are summarized in Tables 1-4.

The ${ }^{1} \mathrm{H}$-NMR, ${ }^{1} \mathrm{Hx}{ }^{1} \mathrm{H}-\mathrm{COSY},{ }^{13} \mathrm{C}-\mathrm{NMR},{ }^{13} \mathrm{Cx}{ }^{1} \mathrm{H}-$ COSY $-{ }^{1} \mathrm{~J}_{\mathrm{CH}}$ and ${ }^{13} \mathrm{Cx}^{1} \mathrm{H}-\mathrm{COSY}-{ }^{\mathrm{n}} \mathrm{J}_{\mathrm{CH}}(\mathrm{n}=2$ and 3) spectra of the 1,3-diarylpropane 1 [2'-hydroxy-4'-methoxy- (1a)] and 2 [4'-hydroxy-2'-methoxy- (2a)] were used to unambiguously assign the ${ }^{1} \mathrm{H}$ and ${ }^{13} \mathrm{C}$ chemical shifts of the aromatic ring $\mathrm{A}$ (Tables 1 and 2) and on the basis of these data to confirm the presence of a 4'-hydroxy-2'methoxyphenyl (ring A) moiety in the structure of the natural 1-(4'-hydroxy-2'-methoxyphenyl)-3-(3"'-hydroxy4' '-methoxyphenyl)propane (5) isolated from Knema austrosiamensis (Myristicaceae) and reported by Gonzaléz et $a l .{ }^{10}$, as well as revealing the interchanged chemical shifts attributed to C-2' and C-4' and $\mathrm{CH}_{2}-1$ (shielded by $\gamma$-effect of the OR located at C-2') and $\mathrm{CH}_{2}-2$. The structure 5, 1-(4'-hydroxy-2'-methoxyphenyl)-3-(3'-hydroxy-4''-me thoxyphenyl)propane, had been previously proposed for a natural product isolated from Virola multinervia ${ }^{4}$. However, this structure was later revised to 1-(2'-hydroxy4'-methoxyphenyl)-3-(3"-hydroxy-4"'- methoxyphenyl) propane ${ }^{7}$. Therefore, the 1,3-diarylpropane 5 isolated from Knema austrosiamensis can be regarded as a novel natural product structure.

Comparative analysis of the ${ }^{1} \mathrm{H}-\mathrm{NMR}$ spectra of the synthetic 1,3-diarylpropanes 6 (previously sinthesized) ${ }^{7}$ and 7 (this paper) with the natural product isolated from $I$. Laevis $^{2}$ showed, as anticipated, small but significant differ-
Table 1. ${ }^{1} \mathrm{H}\left(200 \mathrm{MHz}, \mathrm{CDCl}_{3}\right),{ }^{13} \mathrm{C}\left(50.3 \mathrm{MHz} \mathrm{CDCl}_{3}+\mathrm{MeOH}-\mathrm{d}_{4}\right)$, ${ }^{13} \mathrm{Cx}{ }^{1} \mathrm{H}-\mathrm{COSY}-{ }^{1} \mathrm{~J}_{\mathrm{CH}}$ and ${ }^{13} \mathrm{Cx}{ }^{1} \mathrm{H}-\mathrm{COSY}{ }^{n} \mathrm{~J}_{\mathrm{CH}}(\mathrm{n}=2$ and 3$) \mathrm{NMR}$ of 1-(2'-hydroxy-4'-methoxyphenyl)-3-(4"-hydroxyphenyl)propane (1)*.

\begin{tabular}{|c|c|c|c|c|}
\hline & \multicolumn{2}{|c|}{${ }^{13} \mathrm{Cx}{ }^{1} \mathrm{H}-\mathrm{COSY}-{ }^{1} \mathrm{~J}_{\mathrm{CH}}$} & \multicolumn{2}{|c|}{$\begin{array}{c}{ }^{13} \mathrm{Cx}^{1} \mathrm{H}-\mathrm{COSY}{ }^{-{ }^{\mathrm{n}} \mathrm{J}_{\mathrm{CH}}} \\
(\mathrm{n}=2 \text { and } 3)\end{array}$} \\
\hline & $\delta_{\mathrm{C}}$ & $\delta_{\mathrm{H}}$ & ${ }^{2} \mathrm{~J}_{\mathrm{CH}}$ & ${ }^{3} \mathrm{~J}_{\mathrm{CH}}$ \\
\hline \multicolumn{5}{|l|}{$\mathbf{C}$} \\
\hline 1 & 120.36 & - & $2 \mathrm{H}-1$ & $\begin{array}{c}2 \mathrm{H}-2 ; \mathrm{H}-3^{\prime} ; \\
\text { H-5' }\end{array}$ \\
\hline $2^{\prime}$ & 154.66 & - & H-3' & $2 \mathrm{H}-1 ; \mathrm{H}-6$ \\
\hline 4 & 157.99 & - & H-3'; H-5' & $\mathrm{H}-6$; MeO-4' \\
\hline $1 "$ & 132.94 & - & $2 \mathrm{H}-3$ & $\begin{array}{l}2 \mathrm{H}-2 ; \mathrm{H}- \\
3 ", 5^{\prime \prime}\end{array}$ \\
\hline 4" & 153.83 & - & H-3", 5" & $2 \mathrm{H}-2 ", 6 "$ \\
\hline \multicolumn{5}{|l|}{ CH } \\
\hline 3, & 100.84 & $\begin{array}{c}6.37 \\
(d, \mathrm{~J}=2.5)\end{array}$ & - & H-5, \\
\hline 5 & 103.85 & $\begin{array}{c}6.43 \\
(d d, \mathrm{~J}=8.3 \\
\text { and } 2.5)\end{array}$ & - & $\mathrm{H}-3$, \\
\hline 6 & 129.68 & $\begin{array}{c}7.00 \\
(d, \mathrm{~J}=8.3)\end{array}$ & - & $2 \mathrm{H}-1$ \\
\hline $2^{\prime \prime}$ & 6" & 128.50 & $\begin{array}{c}7.05 \\
(d, \mathrm{~J}=8.5)\end{array}$ & - \\
\hline 3" & $5^{\prime \prime}$ & 114.36 & $\begin{array}{c}6.75 \\
(d, \mathrm{~J}=8.5)\end{array}$ & - \\
\hline \multicolumn{5}{|l|}{$\mathrm{CH}_{2}$} \\
\hline 1 & 28.34 & $\begin{array}{c}2.59 \\
(t, \mathrm{~J}=8.1)\end{array}$ & $2 \mathrm{H}-2$ & H-6 \\
\hline 2 & 31.88 & $1.87(m)$ & $2 \mathrm{H}-3 ; 2 \mathrm{H}-1$ & - \\
\hline 3 & 33.96 & $\begin{array}{c}2.56 \\
(t, \mathrm{~J}=7.5)\end{array}$ & $2 \mathrm{H}-2$ & $2 \mathrm{H}-2 ", 6 "$ \\
\hline \multicolumn{5}{|l|}{$\mathrm{CH}_{3}$} \\
\hline 4'-OMe & 54.03 & $3.76(s)$ & - & - \\
\hline $\mathrm{OH}$ & - & $5.23(s)$ & - & - \\
\hline
\end{tabular}

* Multiplicity of signals of carbon atoms deduced by comparative analysis of PND- and DEPT- ${ }^{13} \mathrm{C}-\mathrm{NMR}$. Homonuclear ${ }^{1} \mathrm{Hx}{ }^{1} \mathrm{H}-\mathrm{COSY}$ spectrum was also used for these assignments. Chemical shifts and coupling constants (J) of the hydrogen atoms were obtained from the ${ }^{1} \mathrm{H}-\mathrm{NMR}$ (1D).

ences in the chemical shifts of H-3' and H-3", which were clearly revealed only after recording these spectra: i) natural product isolated from I. laevis ${ }^{1} \mathrm{H}-\mathrm{NMR}(60 \mathrm{MHz}$, $\left.\mathrm{CDCl}_{3}\right): \delta_{\mathrm{H}} 6.40\left(s l, \mathrm{H}-3^{\prime}\right.$ and $\left.\left.\mathrm{H}-3 "\right), \Delta \delta_{\mathrm{H}}=0 \mathrm{ppm}\right]$; ii) synthetic $6\left[{ }^{1} \mathrm{H}-\mathrm{NMR}\left(100 \mathrm{MHz}, \mathrm{CDCl}_{3}\right): \delta_{\mathrm{H}} 6.37\left(s, \mathrm{H}-3^{\prime}\right)\right.$, $\left.\left.6.32(s, \mathrm{H}-3 "), \Delta \delta_{\mathrm{H}}=0.05 \mathrm{ppm}\right]\right]$; iii) synthetic $7\left[{ }^{1} \mathrm{H}-\mathrm{NMR}\right.$ $\left(200 \mathrm{MHz}, \mathrm{CDCl}_{3}\right): \delta_{\mathrm{H}} 6.38\left(s, \mathrm{H}-3^{\prime}\right), 6.36\left(s, \mathrm{H}-3{ }^{\prime \prime}\right), \Delta \delta_{\mathrm{H}}$ $=0.02 \mathrm{ppm}]$. On the basis of this comparative analysis, the 
Table 2. ${ }^{1} \mathrm{H}\left(200 \mathrm{MHz}, \mathrm{CDCl}_{3}\right),{ }^{13} \mathrm{C}\left(50.3 \mathrm{MHz} \mathrm{CDCl}_{3}+\mathrm{MeOH}-\mathrm{d}_{4}\right)$, ${ }^{13} \mathrm{Cx}^{1} \mathrm{H}-\mathrm{COSY}-{ }_{-}^{1} \mathrm{~J}_{\mathrm{CH}}$ and ${ }^{13} \mathrm{Cx}^{1} \mathrm{H}-\mathrm{COSY}-{ }^{\mathrm{n}} \mathrm{J}_{\mathrm{CH}}(\mathrm{n}=2$ and 3$) \mathrm{NMR}$ of 1-(4'-hydroxy-2'-methoxyphenyl)-3-(4"-hydroxyphenyl)propane (2)*.

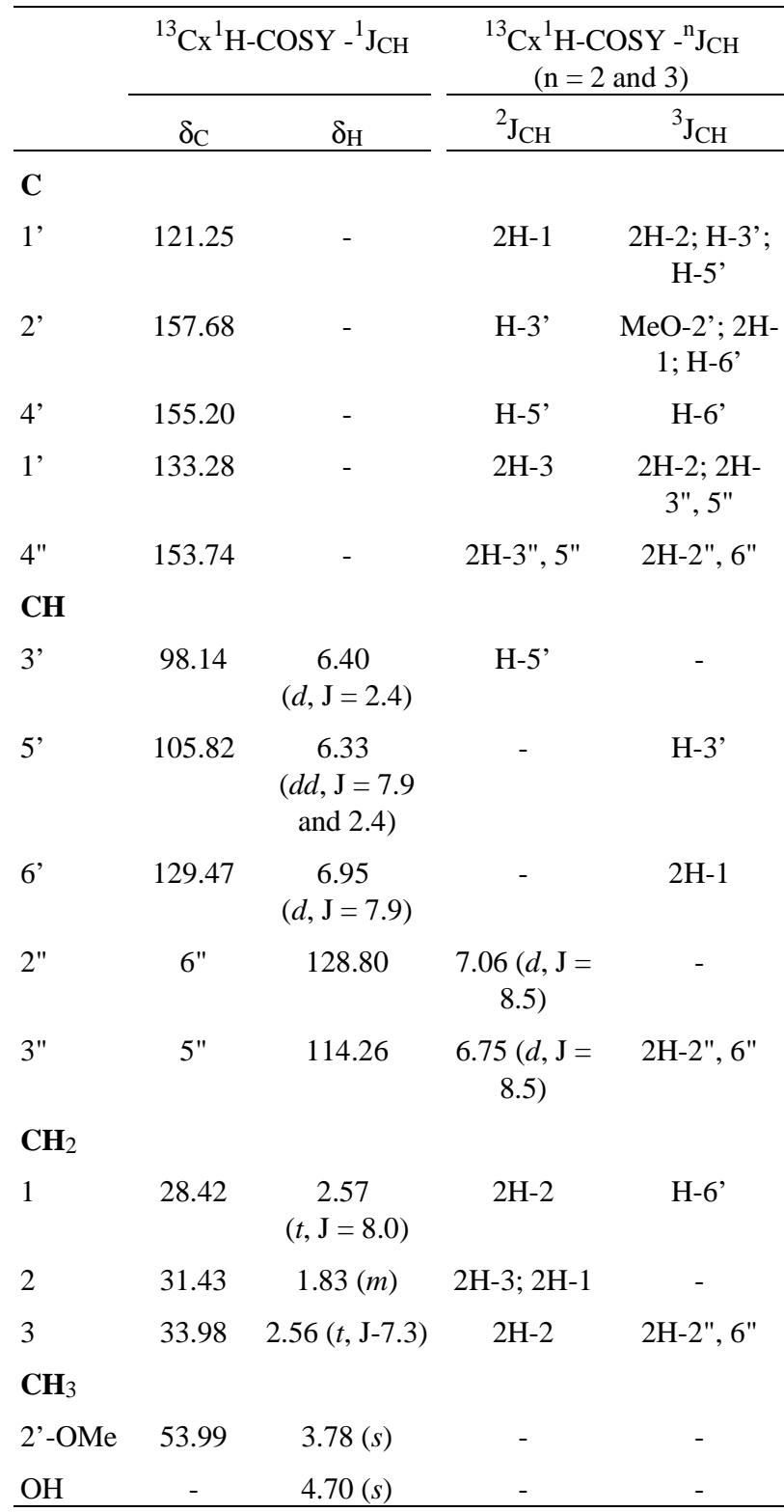

* Multiplicity of signals of carbon atoms deduced by comparative analysis of PND- and DEPT- ${ }^{13} \mathrm{C}-\mathrm{NMR}$. Homonuclear ${ }^{1} \mathrm{Hx}{ }^{1} \mathrm{H}$-COSY spectrum was also used for these assignments. Chemical shifts and coupling constants (J) of the hydrogen atoms were obtained from the ${ }^{1} \mathrm{H}-\mathrm{NMR}$ (1D).

synthetic product 7 confirms the structure proposed ${ }^{7}$ for the natural diarylpropanoid isolated from I. laevis $^{2}$.

Comparison of the ${ }^{13} \mathrm{C}-\mathrm{NMR}$ spectral data of the synthetic 1,3-diarylpropane 7 with values reported by Conserva $e \mathrm{al}^{11}$, for the same natural product isolated later from I. ulei, confirmed the identity of these two compounds. However, the possibility of interchange of the chemical shifts of $\mathrm{C}-1$ ' $\left(\delta_{\mathrm{C}} 119.4\right)$ and $\mathrm{C}-1$ " $\left(\delta_{\mathrm{C}} 119.6\right)$ was re-
Table 3. ${ }^{1} \mathrm{H}\left(200 \mathrm{MHz}, \mathrm{CDCl}_{3}\right),{ }^{13} \mathrm{C}\left(50.3 \mathrm{MHz}, \mathrm{CDCl}_{3}+\mathrm{MeOH}-\mathrm{d}_{4}\right)$, ${ }^{13} \mathrm{Cx}^{1} \mathrm{H}-\mathrm{COSY}-{ }^{1} \mathrm{~J}_{\mathrm{CH}}$ and ${ }^{13} \mathrm{Cx}^{1} \mathrm{H}-\mathrm{COSY}-{ }^{-} \mathrm{J}_{\mathrm{CH}}(\mathrm{n}=2$ and 3) NMR of 1-(2',4'-dimethoxyphenyl)-3-(4"-hydroxyphenyl)propane (4).*

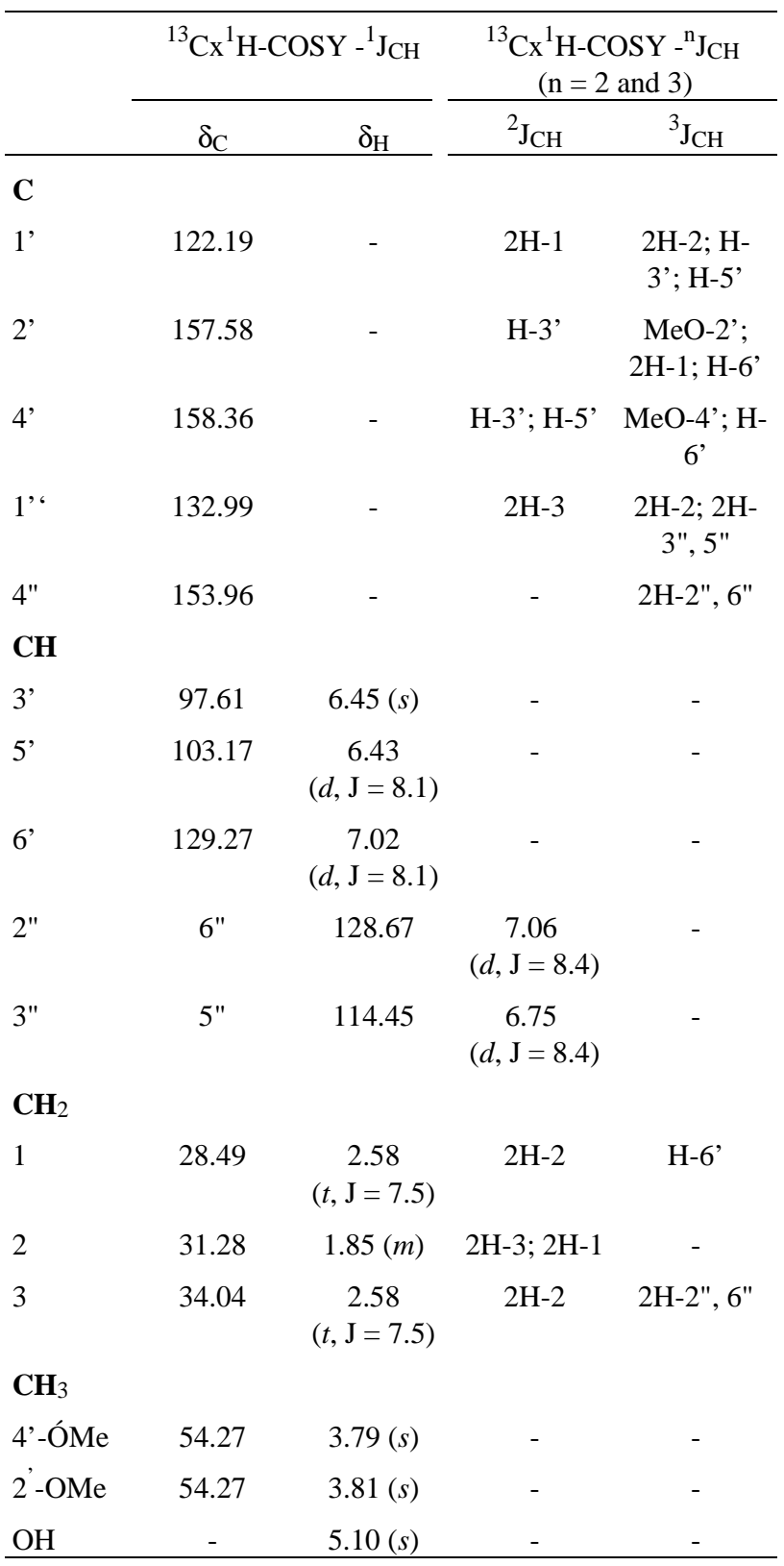

* Multiplicity of signals of carbon atoms deduced by comparative analysis of PND- and DEPT- ${ }^{13} \mathrm{C}-\mathrm{NMR}$. Homonuclear ${ }^{1} \mathrm{Hx}{ }^{1} \mathrm{H}-\mathrm{COSY}$ spectrum was also used for these assignments. Chemical shifts and coupling constants $(\mathrm{J})$ of the hydrogen atoms were obtained from the ${ }^{1}$ H-NMR (1D).

ported ${ }^{11}$. Homonuclear ${ }^{1} \mathrm{H} \mathrm{x}{ }^{1} \mathrm{H}-\mathrm{COSY}$ and heteronuclear ${ }^{13} \mathrm{C} \times{ }^{1} \mathrm{H}-\mathrm{COSY}-{ }^{\mathrm{n}} \mathrm{J}_{\mathrm{CH}}(\mathrm{n}=1 ; \mathrm{n}=2$ and 3, COLOC) $2 \mathrm{D}$ shift-correlated spectra of the synthetic product 7 were used for unambiguous assignment of chemical shifts of hydrogen and carbon atoms (Table 4). In fact, the chemical shifts of the quaternary carbon atoms $\mathrm{C}-1$ ' $\left(\delta_{\mathrm{C}} 119.4\right)$ and C-1", 
Table 4. ${ }^{1} \mathrm{H}\left(200 \mathrm{MHz}, \mathrm{CDCl}_{3}\right),{ }^{13} \mathrm{C}(50.3 \mathrm{MHz}$, acetone-d 6$),{ }^{13} \mathrm{Cx}{ }^{1} \mathrm{H}-$ COSY- ${ }^{1} \mathrm{~J}_{\mathrm{CH}}$ and ${ }^{13} \mathrm{Cx}^{1}{ }^{1} \mathrm{H}-\mathrm{COSY}{ }_{-}{ }^{n} \mathrm{~J}_{\mathrm{CH}}(\mathrm{n}=2$ and 3$)$ NMR of 1-(4'-hydroxy-5'-methyl-2'-methoxyphenyl)-3-(2"-hydroxy-4"-5"-methylenedi oxyphenyl)propane (7)*.

\begin{tabular}{|c|c|c|c|c|}
\hline & \multicolumn{2}{|c|}{${ }^{13} \mathrm{Cx}{ }^{1} \mathrm{H}-\mathrm{COSY}{ }^{-1} \mathrm{~J}_{\mathrm{CH}}$} & \multicolumn{2}{|c|}{$\begin{array}{c}{ }^{13} \mathrm{Cx}^{1} \mathrm{H}-\mathrm{COSY}-{ }^{\mathrm{n}} \mathrm{J}_{\mathrm{CH}} \\
(\mathrm{n}=2 \text { and } 3)\end{array}$} \\
\hline & $\delta \mathrm{C}^{\mathrm{a}}$ & $\delta_{\mathrm{H}}$ & ${ }^{2} \mathrm{~J}_{\mathrm{CH}}$ & ${ }^{3} \mathrm{~J}_{\mathrm{CH}}$ \\
\hline \multicolumn{5}{|l|}{$\mathbf{C}$} \\
\hline 1 , & $121.95(119.4)$ & $2 \mathrm{H}-1$ & H-3, & \\
\hline 2 ' & $156.93(154.9)$ & - & - & $\begin{array}{l}\mathrm{MeO}-2^{\prime} ; \\
\mathrm{H}-6\end{array}$ \\
\hline $4^{\prime}$ & $154.45(152.7)$ & - & - & Me-5'; H-6' \\
\hline 5 , & $115.63(113.7)$ & - & Me-5 & $\mathrm{H}-3$ \\
\hline $1 "$ & $121.35(119.6)$ & - & $2 \mathrm{H}-3$ & H-3" \\
\hline $2^{\prime \prime}$ & $149.88(148.2)$ & - & - & $\begin{array}{c}\mathrm{H}- \\
6 ", \mathrm{OCH}_{2} \mathrm{O} ; \\
2 \mathrm{H}-3\end{array}$ \\
\hline $4 "$ & $146.40(144.3)$ & - & - & 6", $\mathrm{OCH}_{2} \mathrm{O}$ \\
\hline $5 "$ & $141.08(138.8)$ & - & - & H-3" \\
\hline \multicolumn{5}{|l|}{$\mathbf{C H}$} \\
\hline 3, & $99.45(97.5)$ & $6.38(s)$ & - & - \\
\hline 6 & $132.27(130.2)$ & $6.83(s)$ & - & $\mathrm{Me}-5$ \\
\hline $3 "$ & $98.30(96.2)$ & $6.36(s)$ & - & - \\
\hline $6 "$ & $109.90(107.9)$ & $6.59(s)$ & - & $2 \mathrm{H}-3$ \\
\hline \multicolumn{5}{|l|}{$\mathbf{C H}_{2}$} \\
\hline 1 & $29.81(28.2)$ & $\begin{array}{c}2.49 \\
(t, \mathrm{~J}=8.1)\end{array}$ & & H-6, \\
\hline 2 & $31.42(29.5)$ & $1.80(m)$ & $\begin{array}{c}2 \mathrm{H}-3 \\
\text { and/or } \\
2 \mathrm{H}-1\end{array}$ & - \\
\hline 3 & $30.34(27.3)$ & $\begin{array}{c}2.54 \\
(t, \mathrm{~J}=7.2)\end{array}$ & & H-6" \\
\hline $\mathrm{OCH}_{2} \mathrm{O}$ & $101.23(99.2)$ & $5.85(s)$ & - & - \\
\hline \multicolumn{5}{|l|}{$\mathrm{CH}_{3}$} \\
\hline 2'-OMe & $55.42(53.61)$ & $3.74(s)$ & - & - \\
\hline 5'-Me & $15.27(13.31)$ & $2.14(s)$ & - & H-6’ \\
\hline $\mathrm{OH}$ & - & $5.23(s)$ & - & - \\
\hline
\end{tabular}

* Multiplicity of signals of carbon atoms deduced by comparative analysis of PND- and DEPT- ${ }^{13} \mathrm{C}-\mathrm{NMR}$. Homonuclear ${ }^{1} \mathrm{Hx}{ }^{1} \mathrm{H}$-COSY spectrum was also used for these assignments. Chemical shifts and coupling constants (J) of the hydrogen atoms were obtained from the ${ }^{1} \mathrm{H}-\mathrm{NMR}$ (1D). ${ }^{\mathrm{a}}$ Chemical shifts of carbon atoms $\left(50.3 \mathrm{MHz}\right.$, acetone- $\left.\mathrm{d}_{6}\right)$ of natural product 7 (in parenthesis) described in the literature ${ }^{11}$.

$\left(\delta_{\mathrm{C}}\right.$ 119.6) had been interchanged $\left[\delta_{\mathrm{C}} 121.95\left(\mathrm{C}-1^{\prime}\right)\right.$ and $121.35\left(\mathrm{C}-1\right.$ '’)], the same occurring with $\mathrm{C}-1\left(\delta_{\mathrm{C}} 29.81\right)$ and
C-3 $\left(\delta_{\mathrm{C}} 30.34\right)$, as shown in Table 4. Other heteronuclear spin-spin interactions $\left({ }^{\mathrm{n}} \mathrm{J}_{\mathrm{CH}}, \mathrm{n}=1 ; \mathrm{n}=2\right.$ and 3$)$ of hydrogen and carbon- 13 are summarized in Table 4.

Homonuclear ${ }^{1} \mathrm{H} \mathrm{x}{ }^{1} \mathrm{H}-\mathrm{COSY}$ and heteronuclear ${ }^{13} \mathrm{C} \mathrm{x}$ ${ }^{1} \mathrm{H}-\mathrm{COSY}-{ }^{n} \mathrm{~J}_{\mathrm{CH}}(\mathrm{n}=1 ; \mathrm{n}=2$ and 3 , COLOC) $2 \mathrm{D}$ shift-correlated spectra were also used for unambiguous assignment of chemical shifts of hydrogen and carbon atoms of the compounds 1 (Table 1), 2 (Table 2) and 4 (Table 3).

\section{Experimental}

\section{General experimental procedures}

Melting point determinations were made in open capillaries and are uncorrected. Identification of compounds was established by TLC, IR, MS, ${ }^{1} \mathrm{H}-\mathrm{NMR},{ }^{13} \mathrm{C}-\mathrm{NMR}$ (PND and DEPT) and two-dimensional (2D) carbon-hydrogen shift correlation [carbon-hydrogen spin-spin interaction via one bond $\left({ }^{1} \mathrm{~J}_{\mathrm{CH}}\right)$ and two $\left({ }^{2} \mathrm{~J}_{\mathrm{CH}}\right)$ and three $\left({ }^{3} \mathrm{~J}_{\mathrm{CH}}\right)$ bonds, long-range coupling of carbon-hydrogen]. TLC was carried out on Merck kieselgel 60 GF 254. TMS was used as int. standard in NMR spectra. EIMS spectra were recorded at $70 \mathrm{eV}$ on a low resolution spectrometer.

\section{Preparation of the chalcones}

In accordance with the literature ${ }^{12}$, appropriately substituted acetophenones and benzaldehydes gave, by aldol condensation, 8 (yield, $85 \%), \mathbf{9}(88 \%), \mathbf{1 0}(72 \%)$ and 11 $(74 \%)$.

\section{4,4'-Di-O-benzyl-2'-methoxychalcone (8)}

$\mathrm{Mp} 88-90^{\circ}(\mathrm{MeOH}) . \mathrm{IR}$ (neat) 1648, 1620, 1602, 1575 $\mathrm{cm}^{-1} .{ }^{1} \mathrm{H}-\mathrm{NMR}\left(200 \mathrm{MHz}, \mathrm{CDCl}_{3}\right) \delta_{\mathrm{H}} 7.71(d d, \mathrm{~J}=8.5,2,0$ $\mathrm{Hz}, \mathrm{H}-6), 7.63(d, 16.0 \mathrm{~Hz}, \mathrm{H}-7), 7.53(d, \mathrm{~J}=8.3 \mathrm{~Hz}$, 2H-2',6'), 7.36 ( $d, \mathrm{~J}=16.0 \mathrm{~Hz}, \mathrm{H}-8), 7.35$ ( $m$, phenyl), 6.96 $\left(d, \mathrm{~J}=8.3 \mathrm{~Hz}, 2 \mathrm{H}-3^{\prime}, 5^{\prime}\right), 6.61(d, \mathrm{~J}=8.5 \mathrm{~Hz}, \mathrm{H}-5), 6.57(d$, $\mathrm{J}=2.0 \mathrm{~Hz}, \mathrm{H}-3), 5.10\left(s, \mathrm{OCH}_{2} \mathrm{C}_{6} \mathrm{H}_{5}\right), 5.08\left(s, \mathrm{OCH}_{2} \mathrm{C}_{6} \mathrm{H}_{5}\right)$, $3.86(s, \mathrm{OMe})$.

\section{2',4-Di-O-benzyl-4'-methoxychalcone (9)}

Mp 101-103 ${ }^{\circ}(\mathrm{MeOH})$. IR (neat) 1652, 1624, 1604, $1575,1512 \mathrm{~cm}^{-1} .{ }^{1} \mathrm{H}-\mathrm{NMR}\left(200 \mathrm{MHz}, \mathrm{CDCl}_{3}\right) \delta_{\mathrm{H}} 7.89(d$, $\mathrm{J}=8.4 \mathrm{~Hz}, \mathrm{H}-6), 7.66(d, \mathrm{~J}=15.8 \mathrm{~Hz}, \mathrm{H}-7), 7.52(d, \mathrm{~J}=15.8$ $\mathrm{Hz}, \mathrm{H}-8), 7.44-7.26$ ( $m$, phenyl and 2H-2',6'), $6.86(d, \mathrm{~J}=$ $\left.8.9 \mathrm{~Hz}, 2 \mathrm{H}-3^{\prime}, 5\right), 6.60(d d, \mathrm{~J}=8.4$ and $2.4 \mathrm{~Hz}, \mathrm{H}-5), 6.58$ ( $d, \mathrm{~J}=2.4 \mathrm{~Hz}, \mathrm{H}-3), 5.14\left(s, 2^{\prime}-\mathrm{OCH}_{2} \mathrm{C}_{6} \mathrm{H}_{5}\right), 5.10(s$, $\left.4-\mathrm{OCH}_{2} \mathrm{C}_{6} \mathrm{H}_{5}\right), 3.88(s, \mathrm{OMe})$.

\section{4-O-Benzyl-2',4'-dimethoxychalcone (10)}

$\mathrm{Mp} 74-76^{\circ}(\mathrm{MeOH}) . \mathrm{IR}$ (neat) 1644, 1619, 1575, 1512 $\mathrm{cm}^{-1} .{ }^{1} \mathrm{H}-\mathrm{NMR}\left(200 \mathrm{MHz}, \mathrm{CDCl}_{3}\right) \delta_{\mathrm{H}} 7.74(d, \mathrm{~J}=8.5 \mathrm{~Hz}$, $\mathrm{H}-6), 7.65(d, \mathrm{~J}=15.8 \mathrm{~Hz}, \mathrm{H}-7), 7.55(d, \mathrm{~J}=8.8 \mathrm{~Hz}$, 2H-2',6'), 7.39 ( $d$, J = 15.8 Hz, H-8), 7.35 ( $s$, phenyl), 6.99 $\left(d, \mathrm{~J}=8.5 \mathrm{~Hz}, 2 \mathrm{H}-3^{\prime}, 5^{\prime}\right), 6.56(d d, \mathrm{~J}=8.7$ and $2.1 \mathrm{~Hz}, \mathrm{H}-5)$, 
$6.50(d, \mathrm{~J}=2.1 \mathrm{~Hz}, \mathrm{H}-3), 5.11\left(s, \mathrm{OCH}_{2} \mathrm{C}_{6} \mathrm{H}_{5}\right), 3.90(s$, OMe), 3.87 ( $s$, OMe).

4',2-Di-O-benzyl-5'-methyl-4,5-methylenedioxy-2'methoxychalcone (11)

Yellow oil. IR (neat) 1648, 1624,1610, 1580, 1500 $\mathrm{cm}^{-1} .{ }^{1} \mathrm{H}-\mathrm{NMR}\left(200 \mathrm{MHz}, \mathrm{CDCl}_{3}\right) \delta_{\mathrm{H}} 8.06(d, \mathrm{~J}=16.0 \mathrm{~Hz}$, $\mathrm{H}-7$ ), 7.50 ( $d, \mathrm{~J}=16.0 \mathrm{~Hz}, \mathrm{H}-8), 7.53$ ( $s, \mathrm{H}-6), 7.46-7.26$ ( $m$, phenyl), 7.08 ( $s, \mathrm{H}-2$ '), 6.53 ( $s, \mathrm{H}-3), 6.44$ ( $s, \mathrm{H}-6$ '), $5.93\left(s, \mathrm{O}-\mathrm{CH}_{2}-\mathrm{O}\right), 5.13\left(s, \mathrm{OCH}_{2} \mathrm{C}_{6} \mathrm{H}_{5}\right), 3.75(s, \mathrm{OMe})$, $2.20(s, \mathrm{MeAr})$.

\section{Hydrogenation of the chalcones}

A soln. of chalcone $(1 \mathrm{~g})$ in $\mathrm{CHCl}_{3}(5 \mathrm{ml})$ and $\mathrm{EtOH}(50$ $\mathrm{ml})$, in Parr apparatus was flushed with $\mathrm{N}_{2}$. Catalyst $(0.5 \mathrm{~g}$, $10 \% \mathrm{Pd}-\mathrm{C})$ and $\mathrm{AcOH}(10 \mathrm{~mL})$ was added, vacuum applied and $\mathrm{H}_{2}$ was admitted under pressure (50 psi, $4.5 \mathrm{hr}$ ). The usual work-up, followed by crystallization or silica gel chromatography of the crude reaction mixture, gave from $\mathbf{8} \rightarrow \mathbf{2}($ yield $98 \%), \mathbf{9} \rightarrow \mathbf{1}(85 \%), \mathbf{1 0} \rightarrow \mathbf{4}(80 \%)$ and $\mathbf{1 1}$ $\rightarrow 7(90 \%)$.

1-(2'-Hydroxy-4'-methoxyphenyl)-3-(4"-hydroxyphenyl) propane (1)

Mp 81-82 ${ }^{\circ}\left(\mathrm{C}_{6} \mathrm{H}_{6}\right)$. IR (neat) 3388, 1617, 1590, 1512 $\mathrm{cm}^{-1}$. EIMS $m / z$ (rel. int. ): $258\left([\mathrm{M}]^{+}, 20\right), 151(9), 137$ (100), 121 (10), 120 (14), 107 (38), 91 (6). ${ }^{1} \mathrm{H}$ and ${ }^{13} \mathrm{C}-$ NMR: Table 1.

1-(4'-Hydroxy-2'-methoxyphenyl)-3-(4"-hydroxyphenyl) propane (2)

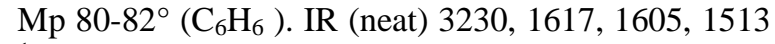
$\mathrm{cm}^{-1}$. EIMS $m / z$ (rel. int.): 258 ([M] $\left.]^{+}, 14\right), 152$ (23), 151 (13), 138 (10), 137 (100), 121 (6), 107 (55), 78 (30), 77 (19). ${ }^{1} \mathrm{H}$ and ${ }^{13} \mathrm{C}-\mathrm{NMR}$ : Table 2 .

1-(2',4'-Dimethoxyphenyl)-3-(4"-hydroxyphenyl) propane (4)

Oil. IR (neat) $3408,1617,1584,1512 \mathrm{~cm}^{-1}$. EIMS $\mathrm{m} / z$ (rel. int.) : $272\left([\mathrm{M}]^{+}, 28\right), 165(10), 151(100), 138(6), 120$ (5). ${ }^{1} \mathrm{H}$ and ${ }^{13} \mathrm{C}-\mathrm{NMR}$ : Table 3.
1-(4'-Hydroxy-5'-methyl-2'-methoxyphenyl)-3(2"-hydroxy-4",5"-methylenedi-oxyphenyl)propane (7)

$\operatorname{Mp} 137-139^{\circ}\left(\mathrm{C}_{6} \mathrm{H}_{6}\right)$. IR (neat) 3322, 1623, 1602, 1520, $1499 \mathrm{~cm}^{-1}$. EIMS $\mathrm{m} / z$ (rel. int.): $316\left([\mathrm{M}]^{+}, 4\right), 178(11)$, 165 (7), 166(25), 152 (26), 151 (100), 149 (10), 121 (16). ${ }^{1} \mathrm{H}$ and ${ }^{13} \mathrm{C}-\mathrm{NMR}$ : Table 4.

\section{Acknowledgments}

The authors are grateful to CAPES and FAPERJ for fellowships and to professor Anselmo A. Morais for furnishing the 2-hydroxy-4,5-methylenedioxybenzaldehyde.

\section{References}

1. Braz-Filho, R.; Leite, M.F.F.; Gottlieb, O.R. Phytochemistry 1972, 12, 417.

2. Braz-Filho, R.; Silva, M.S.; Gottlieb, O.R. Phytochemistry 1980, 19, 1195.

3. Braz-Filho, R.; De Diaz, P.P.; Gottlieb, O.R. Phytochemistry 1980, 19, 455.

4. Braz-Filho, R.; Gottlieb, O.R; Pinho, S.L.V. Phytochemistry 1976, 15, 567.

5. Takasugi, M.; Anetai, M.; Masamune, T.; Shirata, A.; Takahashi, K. Chem. Lett. 1980, 339.

6. Takasugi, M.; Kumagai, Y.; Nagao, S.; Masamune, T.; Shirata, A.; Takahashi, K. Chem. Lett. 1980, 1459.

7. Morais, A.A.; Braz-Filho, R.; Fraiz Júnior, S.V. Phytochemistry 1989, 28, 239.

8. Morais, A.A.; Braz-Filho, R.; Gottlieb, O.R. Phytochemistry 1985, 24, 3023.

9. Ronald, R.C.; Wheeler, C.J. J. Org. Chem. 1984, 49, 1658

10. Gonzaléz, M.J.T.G.; Pinto, M.M.M.; Kijjoa, A.; Anaatachok, C.; Herz, W. Phytochemistry 1993, 32, 433.

11. Conserva, L.M; Yoshida, M.; Gottlieb, O.R. Phytochemistry 1990, 29, 3986.

12. Miquel, J.F. Bull. Soc. Chim. Fr. 1961, 1369. Seshadri, T.R.; Jain, A.C.; Sapal, P.D. Indian J. Chem. 1965, 3, 369.

13. Adams, R. J. Am. Chem. Soc. 1923, 45. 2375.

14. Martin, E.L. Org.Synth. Coll. 1943, 2, 499.

15. Cooper, S.R. Org. Synth. Coll. 1955, 3, 761.

16. Bhrara, C.S.; Jair, C.A;.Seshadri, T.R. Tetrahedron $\mathbf{1 9 6 5}, 21,963$. 